\title{
Cross-country differences in drivers of female necessity entrepreneurship
}

\author{
Pau Sendra-Pons ${ }^{1}$ (D) Sara Belarbi-Muñoz ${ }^{2} \cdot$ Dolores Garzón $^{2} \cdot$ Alicia Mas-Tur $^{2}$
}

Received: 13 April 2021 / Accepted: 8 November 2021 / Published online: 17 November 2021

(c) The Author(s) 2021

\begin{abstract}
This paper analyzes the drivers of female necessity entrepreneurship using a sample of 59 countries, with data sourced from the 2018-2019 global entrepreneurship monitor (GEM). It develops a theoretical framework describing how post-secondary education, startup skills, fear of failure, knowing another entrepreneur, entrepreneurial intentions, and hiring expectations act as drivers of female necessity entrepreneurship. Using qualitative comparative analysis, two models are tested to explain the presence and absence of female necessity entrepreneurship. This outcome is measured using the GEM indicator of total early-stage entrepreneurial activity.
\end{abstract}

Keywords Women entrepreneurship · Global entrepreneurship monitor · Necessity entrepreneurship · QCA

\section{Introduction}

"There is no royal flower-strewn path to success. And if there is, I have not found it... for if I have accomplished anything in life it is because I have been willing to work hard."

Madam Walker

Pau Sendra-Pons

pau.sendra-pons@uv.es

Sara Belarbi-Muñoz

sara.belarbi@uv.es

Dolores Garzón

lola.garzon@uv.es

Alicia Mas-Tur

alicia.mas@uv.es

1 Department of Corporate Finance, Faculty of Economics, Universitat de València, Valencia, Spain

2 Department of Business Management, Faculty of Economics, Universitat de València, Valencia, Spain 
According to Audretsch (2014), the economy has transitioned from one driven by physical capital, as per Solow's model, to, first, one driven by knowledge, as per Romer's model, and then to one driven by entrepreneurship, as per Audretsch's model. This evolution means that, worldwide, entrepreneurship is perceived as the engine of economic and social development (Audretsch 2006). Hence, understanding entrepreneurship and its repercussions for the economy and society have become an issue of growing interest in the literature. As a specific example of these repercussions, Martínez-Rodríguez (2021) empirically showed that more women enter entrepreneurship for necessity than for opportunity, regardless of their home country's GDP.

According to the global entrepreneurship monitor (GEM), entrepreneurship is "any attempt at new business or new venture creation, such as self-employment, a new business organization, or the expansion of an existing business, by an individual, a team of individuals, or an established business." A clear trend in entrepreneurship is the increasing rate of women entrepreneurs, which is growing internationally. Despite this growth, the rate of women entrepreneurship is still low compared to the rate of male entrepreneurship. According to the GEM, the average total earlystage entrepreneurial activity (TEA) was $11.45 \%$ for women and $15.82 \%$ for men in the period 2019-2020. Even though the importance of women entrepreneurship has been recognized by governments, academics (Cardella 2020), and policymakers, especially from the institutional side (Udimal 2020), this phenomenon remains an untapped source of economic growth (Georgeta 2012). Unsurprisingly, diversity in terms of age, religion, nationality, and gender, among others, is a recurring topic in research (Dos Reis et al. 2007).

Given the need to investigate what factors lead to the presence of women entrepreneurship worldwide, the current study uses a sample of 59 countries and qualitative comparative analysis (QCA) to provide causal configurations of conditions that explain both the presence (Model 1) and the absence of female necessity entrepreneurship (Model 2) in different socioeconomically diverse countries. Qualitative comparative analysis (QCA), specifically fuzzy-set qualitative comparative analysis (fsQCA), which is used for continuous data, can reveal causal configurations of logically possible conditions that result in a given outcome. Given the wide range of relationships between social and economic factors and the presence or absence of female necessity entrepreneurship, the study starts by exploring one-directional linear relationships between the factors in the fuzzy model and the outcome. Then, the interactions between these factors are explored by studying the combinations emerging in the resulting causal configurations. Therefore, while this study initially follows a deductive approach focusing on one-directional relationships, the analysis is enriched by the inductive process initiated in the discussion, which reveals interrelationships between these antecedent factors (Ragin 1987). Thus, theoretical and configurational multiplicity emerge in the form of causal recipes, generating twoway knowledge: from theorical background to configurations and vice versa.

The paper is organized as follows. First, the theoretical framework reviews both necessity and opportunity entrepreneurship, as well as women entrepreneurship. It then discusses the conditions employed in the QCA models aimed at explaining the rate of female necessity entrepreneurship. Second, the data and method are 
explained. Third, the results and discussion are presented. Finally, the conclusions, limitations and implications of the study are provided.

\section{Theoretical framework}

\subsection{Necessity, opportunity, and women entrepreneurship}

The GEM report classifies the motivations that drive entrepreneurship using the approach of Reynolds et al. (2005), who differentiated between necessity and opportunity entrepreneurship. Until then, the dominant logic was push-pull theory (Sexton and Vasper 1982; Shapero and Sokol 1982; Hisrich and Brush 1985; Sibanda 2020; Alam et al. 2021). Under this theory, when entrepreneurs consider company creation as a source of income (material or otherwise), a pull force acts. In contrast, when entrepreneurs are forced to find a company to attain a desirable state of living, a push force acts (Giacomin et al. 2011).

However, the most popular classification in the literature, and the one used in the GEM reports, was introduced by Reynolds et al. (2005). Under this approach, the motivation for entrepreneurship is classified as opportunity or necessity. Opportunity entrepreneurship occurs when entrepreneurs identify and exploit a business opportunity, whereas necessity entrepreneurship occurs when entrepreneurs feel forced to undertake a business endeavor because employment alternatives are nonexistent or unsatisfactory (Wennekers et al. 2005). Although the nomenclature is different, there are similarities with push-pull theory, and both classifications relate to the origin or cause of entrepreneurial activity: necessity entrepreneurship corresponds to push motivations, whereas opportunity entrepreneurship corresponds to pull motivations. Later, Caliendo and Kritikos (2019) showed that there is a third type of entrepreneur, namely one who is motivated by both pull and push forces.

Entrepreneurial motivation has been linked to entrepreneurs' level of knowledge about starting a business. A low level of knowledge can lead to greater difficulty in finding a job, which would encourage necessity entrepreneurship (Arenius and Minniti 2005). Necessity-driven entrepreneurship is usually less innovative than opportunity-driven entrepreneurship, which, by its nature, usually requires a higher level of knowledge and is usually more innovative. Nair (2020) provides a discussion of the links between women entrepreneurship and innovation.

Additionally, the literature suggests that the relationship between entrepreneurship and economic development depends on the nature of the entrepreneurship (Audretsch and Keilbach 2008; Aparicio et al. 2016), with opportunity-driven entrepreneurship having a positive relationship with economic development. However, Acs and Varga (2005) concluded that necessity entrepreneurship has no effect.

In recent years, scholars have also highlighted the relationship between women's empowerment and economic development. Duflo (2012), whose research was later developed by Doepke and Tertilt (2019), reported that women's empowerment and economic development are closely related in two ways: development can reduce inequality between genders and women's empowerment may benefit 
development. Sarfaraz et al. (2014) also concluded that both women entrepreneurship and gender equality result in economic development.

Nevertheless, some studies suggest that the motivations behind entrepreneurship differ between men and women (Hisrich and Brush 1985; Orhan and Scott 2001; Manolova et al. 2008). According to the literature, some of the motivations that drive women to engage in entrepreneurial activity are frustration, dissatisfaction at work, the existence of glass ceilings, the need for flexibility to find a worklife balance, the need for inclusion in the labor market, and the need for increased wage income. Ultimately, these motivations are of a social or economic nature. Thus, the distinction between opportunity and necessity entrepreneurship is particularly relevant when considering gender.

As Kelley et al. (2010) noted, in most countries, women are more likely than men to be necessity entrepreneurs. The reasons for this difference were identified by Warnecke (2013). First, the informal economy is usually dominated by women. Second, in developing countries, the educational level of women is usually lower than that of men. Third, access to formal business networks is less likely and access to finance presents more barriers in all countries, regardless of the level of development. Fourth, due to gender norms related to domestic work, women tend to have "time poverty". Necessity entrepreneurs can be considered agents of social change because, through entrepreneurship, they not only improve their employment situation but also influence the environment where they operate. This argument is in line with the development of a social economy after the 2008 financial crisis (Chaves and Monzón 2012). Thus, entrepreneurship is motivated by a need to be included in the labor market and to seek improvements in quality of life (Velásquez et al. 2008).

\subsection{Drivers of female necessity entrepreneurship}

This section discusses the drivers of female necessity entrepreneurship. It provides a theoretical framework of the drivers of female necessity entrepreneurship, which is later taken as the outcome in the QCA. Specifically, the following conditions are used to explain female necessity entrepreneurship: post-secondary education level, entrepreneurial skills, knowing another entrepreneur, job creation expectations, fear of failure, and entrepreneurial intentions.

\subsubsection{Post-secondary education level}

Educational level is cited in the literature as one of the key socioeconomic characteristics in the decision to become an entrepreneur and as an important indicator of entrepreneurial success (Kolstad and Wiig 2015). Education, together with an individual's skills, is responsible for human capital (Becker 1994). Le (1999) identified two channels through which the level of education can influence the propensity to become an entrepreneur. First, through education, individuals can improve their managerial skills, which can increase their willingness to become entrepreneurs. Second, a higher level of education can help people enter the paid market. 
According to Shane (2000), through formal education, individuals become better equipped to learn about markets and technology and to recognize opportunities in their environment. Becker (1964) not only put forward some ideas that were later defended by Shane but also argued that entrepreneurs with higher levels of education want to receive a higher return on their investment. Several authors have argued that education makes it possible to develop skills that then help with the identification of market opportunities (Grant 1996; Shane 2000) and even allow people to engage in knowledge-intensive activities (Bosma et al. 2004). For instance, Audretsch (2012) reported that both education and experience enable entrepreneurs to identify sources of information and know how, thus contributing to firm performance growth. In fact, according to Van der Sluis et al. (2008), the benefits of education for entrepreneurs' performance are quantifiable not only in terms of income (as in the basic human capital model) but also in terms of business survival, firm growth, and return on investment. Additionally, as noted by Gawel (2021), "female entrepreneurship is explained by both male and female education levels" because it generates the right social environment for entrepreneurship promotion.

The GEM Report defines the variable "post-secondary education" [POSED] as the "percentage of 18-64 women (individuals involved in any stage of entrepreneurial activity excluded) indicating to have a post-secondary degree or more" (Reynolds et al. 2005). Much of the literature is based on the assumption that opportunity and necessity entrepreneurs differ in their human capital. Accordingly, individuals with high educational levels would generally be opportunity entrepreneurs (Ucbasaran et al. 2008), whereas necessity entrepreneurs would have difficulties in developing differentiated products and services because of, among other conditions, their educational limitations (Dencker et al. 2009; Poschke 2013). These difficulties are linked to the fact that necessity entrepreneurs have a lower educational level, that their companies are smaller, and that they have less growth potential. However, although much of the literature suggests a positive relationship between educational level and opportunity entrepreneurship, Block and Wagner (2010) concluded that specific vocational education is positively related to the income of necessity entrepreneurs but not to that of opportunity entrepreneurs.

Preposition 1 A lower level of education is conducive to female necessity entrepreneurship.

\subsubsection{Entrepreneurial skills}

Entrepreneurial skills are another source of human capital, together with knowledge, abilities, experience, and training. Being an entrepreneur requires the execution of a wide variety of tasks that may require different skills. According to Lazear (2004), as a consequence, entrepreneurs must be "jacks of all trades" (JATs). That is, they do not have to be experts in any particular skill or area, but they have to be good enough in a wide variety of skills or areas for the business not to fail. He also reported that JATs have a higher probability of becoming entrepreneurs. This positive relationship between the variety of skills and entrepreneurial activity has been confirmed by other authors (e.g., Wagner 2003; Baumol 2005). In fact, based on 
JAT theory, Stuetzer et al. (2013) concluded that entrepreneurs with varied professional experience have greater entrepreneurial skills and that this greater skill level increases their tendency to engage and persist in entrepreneurial activities.

The GEM report defines the variable "startup skills" [SKILL] as the "percentage of adults aged 18-64 indicating to have the required skills and knowledge to set up a business" (Reynolds et al. 2005). According to this definition, the skills variable is measured based on an individual's self-perception of skills, knowledge, and abilities. Therefore, the term "perceived self-efficacy" plays an important role when analyzing the skills variable. This concept was introduced by Bandura in 1977 to refer to individuals' perceptions of their ability to influence events that occur in their lives (Bandura 2010). In entrepreneurship, an individual's ability to start a successful entrepreneurial venture is measured through entrepreneurial self-efficacy (Chen et al. 1998). Several studies linking this variable to entrepreneurial intentions (Chen et al. 1998; Krueger and Brazeal 1994) have empirically shown a positive relationship between entrepreneurial self-efficacy and entrepreneurial intentions. However, fear of failure can negatively alter that relationship ( $\mathrm{Ng}$ and Jenkins 2018). In addition, self-efficacy facilitates entrepreneurs' opportunity detection (Shane 2000), which should encourage opportunity entrepreneurship.

Considering gender, Bandura (1992) argued that women are more likely to limit their career aspirations because they believe they lack the necessary skills. Eccles (1994) reported that there are social and psychological reasons why women are still underrepresented in some occupational and educational areas. These gender differences are mainly observed in areas that have been stereotypically linked to "masculine" skills, including business and entrepreneurship careers (Wilson et al. 2007). Koellinger et al. (2013) concluded that women have more fear of failure and less confidence in their entrepreneurial skills than men and are less likely to know other entrepreneurs than men. According to these authors, greater fear of failure, lower self-confidence and less exposure to other entrepreneurs are factors that reduce women's propensity to start a business.

Preposition 2 Entrepreneurial skills are not conducive to female necessity entrepreneurship.

\subsubsection{Knowing an entrepreneur}

As discussed, human capital is the set of experiences, training, knowledge, skills, and capabilities that define and add value to a person's profile. This human capital is complemented by social capital, which is regarded as "friends, colleagues, and more general contacts through whom you receive opportunities to use other forms of capital" (Burt 1992, p 9). According to this definition, social capital depends on interaction with other agents. Forret (2006) argued that, although individuals tend to develop human capital, this human capital is not enough. Hence, the development of social capital provides individuals with a formidable professional advantage. In addition, social capital is more difficult to imitate than human capital because relationships are unique, valuable, and not replicable. 
The GEM report defines the variable "knowing entrepreneurs" [KNOW] as referring to any entrepreneur who "personally knows someone who started a firm in the last two years" (Reynolds et al. 2005). The influence of others is often crucial in the decision to become an entrepreneur (Bosma et al. 2012). The literature explains that peer influence can affect entrepreneurial potential in several ways by providing role models and access to networks and knowledge (Markussen and Røed 2017). In addition, knowledge transfer can reduce the level of uncertainty experienced by potential entrepreneurs (Wyrwich et al. 2016). Perceiving similarities in certain attributes is a key factor when selecting role models (Byrne 1971; Gibson 2004). In particularly, perceiving demographic similarities intensifies interpersonal attraction (Ibarra 1992). Gender is a demographic attribute that can lead to similarity perception and can thus influence the selection of role models. In line with this idea, Markussen and Røed (2017) concluded that, generally, same-sex peers have a greater influence than opposite-sex peers and that this gender-based influence explains the existence of a gender gap in entrepreneurship. Rocha and Van Praag (2020) have observed that the influence of women company founders on female workers is even greater than the influence of other social interactions such as that exerted by interactions with peers or parents.

Klyver and Grant (2010) showed that individuals who know an entrepreneur show a greater tendency to become entrepreneurs. However, women are less likely to know an entrepreneur. The reasons are a lack of resource providers or a lack of role models in their networks. Warnecke (2013) went further, explaining that it is more difficult for women to access formal business networks. When having entrepreneurial connections is linked to entrepreneurial motivation, Wagner (2005) found that opportunity entrepreneurs are more likely than necessity entrepreneurs to have a role model in the family. In contrast, Morales-Gualdrón and Roig (2005) argued that the influence of knowing an entrepreneur is equivalent for both types of entrepreneurship.

Preposition 3 Knowing an entrepreneur is not conducive to female necessity entrepreneurship.

\subsubsection{Job creation expectation}

In recent years, entrepreneurship has been seen as an opportunity to create jobs and contribute to economic development. Despite a lack of consensus on the relationship between entrepreneurship and job creation and the effects of entrepreneurship on job creation (Fritsch and Muellero 2004), research has identified a clear link between the two (Badal 2010). However, some literature suggests that the contribution of employment to economic development depends on the reason for starting a business. Opportunity-driven entrepreneurship has a positive relationship with economic development, whereas necessity entrepreneurship has no effect (Acs and Varga 2005).

The GEM report defines the variable "high job creation expectation rate" [HIRES] as the "percentage of those involved in TEA who expect to create 6 or more jobs in 5 years". The literature on this variable treats it as closely related to 
firm growth expectations and links it to the term "high-growth entrepreneurship". Just as the literature classifies entrepreneurs according to their motivation (i.e., necessity vs. opportunity), it emphasizes the existence of "solo entrepreneurs". According to GEM, a solo entrepreneur is an entrepreneur "that operates on their own, with no co-founders or employees, and projecting no hiring".

When analyzing the hiring expectations of entrepreneurs, it is important to differentiate between solo entrepreneurs and those who enter the world of entrepreneurship to found and grow a company. According to Fairlie and Fossen (2018), three quarters of necessity entrepreneurs are solo entrepreneurs, whereas only 53\% of opportunity entrepreneurs are solo entrepreneurs. This gap implies that opportunity entrepreneurs are more likely to contribute to job creation than necessity entrepreneurs. Additionally, according to Bergmann and Sternberg (2007, p 206), "the majority of necessity entrepreneurs are primarily looking to safeguard their own living, not to generate revenue growth or additional jobs."

The hiring expectations of solo entrepreneurs have been studied by Van Stel et al. (2020), who concluded that solo entrepreneurs with high educational levels tend to have low hiring intentions and that these low intentions are due to the need for autonomy and self-expression or self-realization. Darnihamedani and Terjesen (2020) analyzed the hiring expectations of entrepreneurs from the perspective of regulatory efficiency, composed of business freedom, labor freedom, and monetary freedom. After analyzing 68 countries, they concluded that entrepreneurs in countries with fewer labor restrictions and greater monetary freedom have higher growth ambitions. Moreover, these conclusions are accentuated when gender is considered, with men having higher growth ambitions than women.

\section{Preposition 4 Hiring expectations are not conducive to female necessity entrepreneurship.}

\subsubsection{Fear of failure}

According to Frank Knight, risk occurs when the future is unknown, but the probability of the future is "known". In contrast, uncertainty occurs when the probability is unknown (Runde 1998). Thus, coping with uncertainty and predicting what will happen in the future is one of the biggest challenges that entrepreneurs have to face (Forrester 1971). Traditionally, entrepreneurs have been perceived as risk takers. Some of the literature depicts fear of failure as an attitude towards risk. Fear of failure continues to be one of the factors that is most feared by entrepreneurs, and much of the literature identifies it as a barrier to entrepreneurship. Several studies have shown that fear of failure has a negative relationship with entrepreneurial activity (e.g., Arenius and Minniti 2005; Ardagna and Lusardi 2010). In a society where success and achievement are so important, the possibility of failure is often minimized or even denied (Rothblum 1990). According to the GEM report, "fear of failure" FAILU is defined as the "percentage of 18-64 women (individuals involved in any stage of entrepreneurial activity excluded) who indicate that fear of failure would prevent them from setting up a business." 
The relationship between fear of failure and entrepreneurship has also been analyzed by differentiating between opportunity and necessity entrepreneurship. According to Morales-Gualdrón and Roig (2005), this negative relationship between fear of failure and entrepreneurship is present in both types of entrepreneurs but is accentuated in necessity entrepreneurs (Morales-Gualdrón and Roig 2005). Some studies have shown that opportunity entrepreneurs are more willing to accept risks than necessity entrepreneurs (Brünjes and Diez 2013; Block et al. 2015). Wagner (2005) concluded that fear of failure is lower among opportunity entrepreneurs. However, conceiving fear of failure as a negative emotion, Cacciotti and Hayton (2014) argued that risk aversion is a simplistic conceptualization of fear of failure. Several studies have shown that fear of failure can not only inhibit entrepreneurs but also have a motivational effect (Ray 1994; Cacciotti et al. 2016).

With respect to gender, most articles report that men and women perceive fear of failure differently, which can be linked to the gender gap in entrepreneurship (Wagner 2007). Several studies suggest that women are more risk averse and thus less risk tolerant than men (Johnson and Powell 1994; Eckel and Grossman 2003). They also suggest that women consider fear of failure to be an obstacle to entrepreneurship. In fact, fear of failure and women's perceptions of their capabilities and skills are two of the most common subjective variables in the literature on the barriers to women entrepreneurship and the gender gap.

Preposition 5 Fear of failure is not conducive to female necessity entrepreneurship.

\subsubsection{Entrepreneurial intentions}

The models that are most commonly used to study entrepreneurship from the perspective of intentions are the theory of planned behavior, proposed by Ajzen (1991), and the entrepreneurial event model of Shapero and Sokol (1982). One of the main elements in the theory of planned behavior is the individual's intention to carry out a specific behavior. This intention captures a motivating element in that the more intense the intention is, the more likely an individual will be to carry out the action (Ajzen 1991). In contrast, the event model seeks to explain why individuals become entrepreneurs, describing an entrepreneurial event as the result of an individual's perceptions in terms of desire and feasibility. In the model described by Ajzen (1991), intention is influenced by "personal attitude, subjective norm and perceived behavioral control." These two models have served as the basis for new models aimed at explaining entrepreneurial intentions (Krueger and Carsrud 1993; Boyd and Vozikis 1994) and have generally been applied in an educational context focusing on opportunity entrepreneurship. In fostering entrepreneurial intentions, culture, which has been found to be crucial in creating high growth expectations among female entrepreneurs, is decisive (Xie et al. 2021). For example, Anggadwita (2021) found that sociocultural environment has a positive effect on a woman's intention to become an entrepreneur.

The GEM report defines "entrepreneurial intentions" INTEN as "the percentage of 18-64 population (individuals involved in any stage of entrepreneurial activity excluded) who are latent entrepreneurs and who intend to start a business within 
three years." Bird (1988) affirmed that the intentional process starts with an entrepreneur's needs, values, wants, habits, and beliefs. Accordingly, the assumption is that different necessities may lead to different entrepreneurial intentions. This assumption has been tested by Lucas and Cooper (2012), who concluded that one of the effects of necessity is its direct influence on intentions. However, given the lack of literature linking necessity-driven entrepreneurship and entrepreneurial intentions, the results of the aforementioned study should be further tested.

In terms of gender, Strobl et al. (2012) found that men have stronger entrepreneurial intentions than women. Haus et al. (2013) supported this idea, concluding that men are more likely to transform their intentions into actions. There are also numerous studies relating entrepreneurial intentions with all the variables described throughout this paper (Krueger and Brazeal 1994; Chen et al. 1998; Do Paço et al. 2015; Ng and Jenkins 2018).

Preposition 6 Entrepreneurial intentions are not conducive to female necessity entrepreneurship.

\section{Data and method}

\subsection{Data}

The data used in this study were gathered from the 2018/2019 Women's Entrepreneurship Report issued by the GEM. The outcome was female necessity total early-stage entrepreneurial activity (TEA). The conditions analyzed in the study are reported in the following Table 1.

The sample covered 59 countries: Angola, Argentina, Australia, Austria, Bosnia and Herzegovina, Brazil, Bulgaria, Canada, Chile, China, Colombia, Croatia, Cyprus, Ecuador, Egypt, Estonia, France, Germany, Greece, Guatemala, India, Indonesia, Iran, Ireland, Israel, Italy, Japan, Kazakhstan, Republic of Korea, Latvia, Lebanon, Luxembourg, Madagascar, Malaysia, Mexico, Morocco, Netherlands, Panama, Peru, Poland, Puerto Rico, Qatar, Russian Federation, Saudi Arabia, Slovak Republic, Slovenia, South Africa, Spain, Sudan, Sweden, Switzerland, Taiwan, Thailand, Turkey, United Arab Emirates, United Kingdom, United States, Uruguay, and Vietnam.

\subsection{Method}

Qualitative comparative analysis (QCA) was used to study the causality of conditions leading to a given outcome in a systematic way. There are several methodological variants of QCA, all of which enable the evaluation of different conjectured causes of a given outcome. Fuzzy-set qualitative comparative analysis (fsQCA) was used in this study. This approach differs from crisp-set qualitative comparative analysis (csQCA) in that it permits the use of continuous data, whereas csQCA uses 
Table 1 Conditions used in the study

\begin{tabular}{|c|c|}
\hline Conditions & Definition \\
\hline $\begin{array}{l}\text { Women TEA post-secondary education } \\
\text { POSED }\end{array}$ & $\begin{array}{l}\text { Percentage of } 18-64 \text { women (individuals involved in any } \\
\text { stage of entrepreneurial activity excluded) indicating to } \\
\text { have a post-secondary degree or more }\end{array}$ \\
\hline $\begin{array}{l}\text { Women have startup skills } \\
\text { SKILL }\end{array}$ & $\begin{array}{l}\text { Percentage of } 18-64 \text { women (individuals involved in any } \\
\text { stage of entrepreneurial activity excluded) who believe } \\
\text { they have the required skills and knowledge to start a } \\
\text { business }\end{array}$ \\
\hline $\begin{array}{l}\text { Women personally knows an entrepreneur } \\
\text { KNOW }\end{array}$ & $\begin{array}{l}\text { Percentage of } 18-64 \text { women (individuals involved in any } \\
\text { stage of entrepreneurial activity excluded) who indicate } \\
\text { that they personally know someone who started a firm } \\
\text { in the past two years }\end{array}$ \\
\hline $\begin{array}{l}\text { Women expecting } 6+\text { hires in next five years } \\
\text { HIRES }\end{array}$ & $\begin{array}{l}\text { Percentage of those involved in TEA who expect to cre- } \\
\text { ate } 6 \text { or more jobs in } 5 \text { years }\end{array}$ \\
\hline $\begin{array}{l}\text { Women undeterred by fear of failure } \\
\text { FAILU }\end{array}$ & $\begin{array}{l}\text { Percentage of } 18-64 \text { women (individuals involved in any } \\
\text { stage of entrepreneurial activity excluded) who indicate } \\
\text { that fear of failure would prevent them from setting up } \\
\text { a business }\end{array}$ \\
\hline $\begin{array}{l}\text { Women entrepreneurial intentions } \\
\text { INTEN }\end{array}$ & $\begin{array}{l}\text { Percentage of } 18-64 \text { population (individuals involved in } \\
\text { any stage of entrepreneurial activity excluded) who are } \\
\text { latent entrepreneurs and who intend to start a business } \\
\text { within three years }\end{array}$ \\
\hline
\end{tabular}

Source: GEM-Reynolds (2015)

dichotomous data. Using this method and the data sourced from the GEM, a crosssectional study was carried out for the period 2018-2019.

To determine which combinations of conditions lead to the presence or absence of female necessity entrepreneurship in the current sample of countries, two models were designed. The outcome analyzed in Model 1 was the presence of female necessity entrepreneurship, measured as the indicator of female necessity total-early state entrepreneurial activity (TEA) provided by the GEM. The outcome in Model 2 was the absence of female necessity entrepreneurship. Both models were considered because, under the concept of asymmetric causality, knowing the causes of the presence of a given outcome does not automatically reveal the causes of the absence of that outcome. The models can be stated as follows:

Model 1: NECTEA = f(POSED, SKILL, KNOW, HIRES, FAILU, INTEN).

Model 2: NECTEA =f(POSED, SKILL, KNOW, HIRES, FAILU, INTEN).

Note: NECETA refers to female necessity total-early state entrepreneurial activity (TEA) provided by the global entrepreneurship monitor (GEM). 
Table 2 Analysis of necessary conditions

\begin{tabular}{llllll}
\hline Condition & \multicolumn{2}{l}{ Outcome: NECTEA } & & \multicolumn{2}{l}{ Outcome: NECTEA } \\
\cline { 2 - 3 } \cline { 6 - 6 } \cline { 6 - 6 } & Consistency & Coverage & & Consistency & Coverage \\
\hline POSED & 0.582430 & 0.571620 & 0.580368 & 0.579608 \\
$\sim$ POSED & 0.571658 & 0.572422 & 0.571059 & 0.581872 \\
SKILL & 0.653421 & 0.610733 & 0.544208 & 0.517595 \\
$\sim$ SKILL & 0.483876 & 0.510591 & 0.590718 & 0.634287 \\
FAILU & 0.633314 & 0.611908 & 0.534261 & 0.525276 \\
$\sim$ FAILU & 0.508669 & 0.517680 & 0.605269 & 0.626819 \\
ENTRE & 0.549875 & 0.530623 & 0.622307 & 0.611075 \\
$\sim$ ENTRE & 0.596963 & 0.608343 & 0.521995 & 0.541295 \\
INTEN & 0.636836 & 0.651518 & 0.479047 & 0.498705 \\
$\sim$ INTEN & 0.510002 & 0.490334 & 0.665255 & 0.650842 \\
HIRES & 0.638888 & 0.635390 & 0.480694 & 0.486464 \\
$\sim$ HIRES & 0.483637 & 0.477869 & 0.639715 & 0.643195 \\
\hline
\end{tabular}

The symbol " " refers to the negation of a condition. For example, " POSED" refers to the absence of post-secondary education

\section{Results and discussion}

First, analysis of necessary conditions was conducted. Given that no condition had a consistency greater than 0.9 (Cruz-Ros et al. 2017), this analysis indicates that no condition is necessary for the presence or absence of female necessity entrepreneurship (Table 2).

Second, although no condition was found to be necessary at the individual level in either of the two models (consistency less than 0.9 in all cases), the fsQCA method can be used to obtain causal configurations of several conditions that explain the outcome (Table 3).

Overall, proposition one is rejected. For the rest of the propositions, the results are mixed. Some causal configurations include conditions in line with the propositions,

Table 3 Parsimonious solution for model 1

\begin{tabular}{|c|c|c|c|}
\hline Causal configuration & Raw coverage ${ }^{a}$ & Unique coverage $^{\mathrm{b}}$ & Consistency \\
\hline SKILL* $\sim$ KNOW* $*$ INTEN & 0.204767 & 0.050884 & 0.761445 \\
\hline SKILL* $\sim$ FAILU* $\sim$ KNOW & 0.227713 & 0.019253 & 0.869208 \\
\hline$\sim$ KNOW*INTEN*HIRES & 0.288821 & 0.092501 & 0.793201 \\
\hline SKILL*FAILU*KNOW*INTEN & 0.232808 & 0.006155 & 0.871145 \\
\hline SKILL*INTEN*HIRES & 0.333994 & 0.031221 & 0.825055 \\
\hline
\end{tabular}

Solution coverage: 0.575351 , solution consistency: 0.77991

andicates the proportion of the outcome explained by a certain solution

${ }^{b}$ Indicates the proportion of the outcome explained by each individual condition in the causal configuration (Florea et al. 2019) 
whereas others do not. No causal configuration includes either the presence or absence of post-secondary education.

The five causal configurations in the parsimonious solution for Model 1 explain approximately $57 \%$ of the empirical cases, as reflected by the solution coverage of 0.575351 . The first causal configuration of conditions in the parsimonious solution attributes the presence of female necessity entrepreneurship to the presence of entrepreneurial skills, the absence of knowing another entrepreneur, and the absence of entrepreneurial intentions. For this causal configuration, South Africa (0.841, $0.928)$, Argentina $(0.718,0.953)$, Spain $(0.625,0.633)$, and Ireland $(0.559,0.237)$ have high levels of female necessity entrepreneurship. That is, their membership in this configuration is greater than 0.5 . The second causal configuration combines the presence of entrepreneurial skills with the absence of fear of failure and the absence of knowing another entrepreneur. Uruguay $(0.754,0.943)$, India $(0.628,0.999)$, Ireland $(0.559,0.237)$, and Spain $(0.546,0.633)$ have a membership greater than 0.5 . The third causal configuration consists of not knowing other entrepreneurs but having entrepreneurial intentions and hiring expectations. It applies to Ecuador (0.994, 0.997), Egypt (0.847, 0.998), Guatemala (0.727, 0.995), Turkey (0.708, 0.047), India (0.632, 0.999), Republic of Korea (0.598, 0.249), Madagascar (0.586, 0.925), and Qatar $(0.547,0.123)$, each with a membership greater than 0.5 . The fourth causal configuration combines four conditions: the presence of entrepreneurial skills, fear of failure, knowing other entrepreneurs, and entrepreneurial intentions. Countries with a membership greater than 0.5 are Saudi Arabia $(0.809,0.98)$, Indonesia $(0.68,0.711)$, Lebanon $(0.667,0.953)$, and Angola $(0.52,0.999)$. Finally, the fifth causal configuration consists of the presence of entrepreneurial skills, intentions, and hiring expectations. Sudan $(0.996,0.977)$, Ecuador $(0.814,0.997)$, Saudi Arabia (0.809, 0.98), Lebanon $(0.793,0.953)$, Peru $(0.783,0.402)$, Turkey $(0.708,0.047)$, Indonesia $(0.68,0.711)$, Qatar $(0.676,0.123)$, and India $(0.628,0.999)$ all have a membership greater than 0.5 . When allowing for interactions between factors, the linear relationships described in the propositions are no longer valid, offering a wide range of causal multiplicity, i.e., combinations of conditions.

In Model 2, the outcome was the absence of female necessity entrepreneurship. Three causal configurations were found (Table 4). The first consists of the absence of entrepreneurial skills, entrepreneurial intentions, and knowing another entrepreneur. The second configuration attributes the absence of female necessity entrepreneurship to the absence of hiring expectations, despite the absence of fear of failure and the presence of knowing other entrepreneurs. Finally, the third causal configuration consists of the absence of entrepreneurial skills and the presence of fear of failure and entrepreneurial intentions. These intentions are normally conducive

Table 4 Parsimonious solution for model 2

\begin{tabular}{llll}
\hline Causal configuration & Raw coverage & Unique coverage & Consistency \\
\hline$\sim$ SKILL* $\sim$ KNOW $^{*} \sim$ INTEN & 0.264072 & 0.125550 & 0.756887 \\
$\sim$ FAILU*KNOW $*$ HIRES & 0.298350 & 0.184494 & 0.851280 \\
$\sim$ SKILL*FAILU*INTEN & 0.214101 & 0.074201 & 0.879365 \\
\hline
\end{tabular}

Solution coverage: 0.542965 , solution consistency: 0.784625 
Table 5 Analysis of sufficient conditions for models 1 and 2

\begin{tabular}{|c|c|c|c|c|c|c|c|c|}
\hline \multirow[b]{2}{*}{$\begin{array}{c}\text { Configuration } \\
\text { No. }\end{array}$} & \multicolumn{5}{|c|}{ High rates of women entrepreneurship by necessity } & \multicolumn{3}{|c|}{$\begin{array}{c}\text { Low rates of women } \\
\text { entrepreneurship by necessity }\end{array}$} \\
\hline & 1 & 2 & 3 & 4 & 5 & 6 & 7 & 8 \\
\hline \multicolumn{9}{|l|}{ POSED } \\
\hline SKILL & - & $\bullet$ & & ○ & $\bullet$ & 0 & & 0 \\
\hline KNOW & $\mathbf{0}$ & $\mathbf{0}$ & $\mathbf{0}$ & ○ & & $\mathbf{0}$ & 0 & \\
\hline HIRES & & & $\bullet$ & & $\bullet$ & & 0 & \\
\hline FAILU & & $\mathbf{0}$ & & 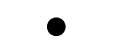 & & & $\mathbf{0}$ & 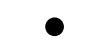 \\
\hline INTEN & $\mathbf{0}$ & & 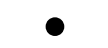 & 0 & 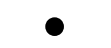 & $\mathbf{0}$ & & ○ \\
\hline Raw coverage & 0.204767 & 0.227713 & 0.288821 & 0.232808 & 0.333994 & 0.264072 & 0.298350 & 0.214101 \\
\hline $\begin{array}{c}\text { Unique } \\
\text { coverage }\end{array}$ & 0.050884 & 0.019253 & 0.092501 & 0.006155 & 0.031221 & 0.125550 & 0.184494 & 0.074201 \\
\hline Consistency & 0.761445 & 0.869208 & 0.793201 & 0.871145 & 0.825055 & 0.756887 & 0.851280 & 0.879365 \\
\hline $\begin{array}{l}\text { Solution } \\
\text { coverage }\end{array}$ & & & 0.575351 & & & & 0.542965 & \\
\hline $\begin{array}{c}\text { Solution } \\
\text { consistency }\end{array}$ & & & 0.77991 & & & & 0.784625 & \\
\hline
\end{tabular}

Black circles indicate the presence of the condition. White circles indicate the absence of the condition

to opportunity entrepreneurship, whereas necessity entrepreneurship is generally linked to economic survival. Table 5 summarizes results on both models.

\section{Conclusions}

Building on a literature-based theoretical framework that offers six linear propositions regarding the conditions that explain necessity entrepreneurship, this paper presents two models: one that explains the presence of female necessity entrepreneurship and one that explains its absence. Data were sourced from the GEM, and fsQCA was then applied to these data.

Ultimately, the results for Model 1 provide five causal configurations of logically feasible conditions that explain the presence of necessity entrepreneurship in different countries. The results provide information about the countries that each configuration applies to with a membership greater than 0.5. In terms of explaining the absence of such female necessity entrepreneurship, the solution for Model 2 presents three causal configurations. In Model 1, the presence of entrepreneurial skills is a recurring condition when explaining the presence of female necessity entrepreneurship. Likewise, in Model 2, the lack of such skills is a recurring explanatory condition in explaining the absence of female necessity entrepreneurship. This finding is in line with the fact that women entrepreneurs, even when engaging in necessity entrepreneurship, seem to have a high level of skills. This attribute could 
hypothetically support the conversion from necessity entrepreneurship to opportunity entrepreneurship.

In short, this study provides a better understanding of what combinations of conditions foster both the presence and absence of female necessity entrepreneurship. Although the study was limited by the size of the sample and its cross-sectional nature, it contributes to the literature on entrepreneurship and has practical policymaking implications by highlighting the aspects that should be fostered to promote this type of entrepreneurship. In particular, as explained earlier, skills matter even for necessity entrepreneurship. These skills could be further supported by policies in favor of women's acquisition of a skills toolkit through government-supported training programs. Entrepreneurial skills are present in most of the causal configurations, and the promotion of these skills is crucial for necessity entrepreneurship. Indeed, even when individuals do not know another entrepreneur or have entrepreneurial intentions, the presence of skills is conducive to female necessity entrepreneurship. The presence of entrepreneurial intentions, along with other factors, similarly emerges as conducive to female necessity entrepreneurship. This finding highlights the importance of creating a culture that encourages these intentions. In addition to programs to promote entrepreneurial intentions, often led by governmental organizations, it would also be worth developing programs to facilitate third-party hiring. A crucial aspect of necessity entrepreneurship is the drive to ensure that close family and friends are supported financially. This aspect is reflected by the fact that hiring third parties is a recurring condition in the causal configurations.

As for the limitations of the study, because it was cross-sectional, it was not possible to analyze the evolution of the causal configurations conducive to the presence and absence of female necessity entrepreneurship over time. In addition, the sample, which covered 59 countries, could be expanded. Future lines of research could therefore consider a longitudinal study, as well as including a larger number of countries in the analysis, thus making it possible to form groups of countries with similar socioeconomic characteristics that present the same causal configurations. Additionally, it would be of interest to analyze women's motivations to become necessity entrepreneurs at the individual level because assumptions of homogeneity might mask differences between different groups of women (Brush and Greene 2021).

Acknowledgements Alicia Mas-Tur thanks the Generalitat Valenciana for funding under Project GV/2021/121 to support this research. Pau Sendra-Pons thanks the Spanish Ministry of Universities for funding under FPU2019/00867 to support this research.

Funding Open Access funding provided thanks to the CRUE-CSIC agreement with Springer Nature.

Open Access This article is licensed under a Creative Commons Attribution 4.0 International License, which permits use, sharing, adaptation, distribution and reproduction in any medium or format, as long as you give appropriate credit to the original author(s) and the source, provide a link to the Creative Commons licence, and indicate if changes were made. The images or other third party material in this article are included in the article's Creative Commons licence, unless indicated otherwise in a credit line to the material. If material is not included in the article's Creative Commons licence and your intended use is not permitted by statutory regulation or exceeds the permitted use, you will need to obtain permission directly from the copyright holder. To view a copy of this licence, visit http://creativecommons.org/licen ses/by/4.0/. 


\section{References}

Acs ZJ, Varga A (2005) Entrepreneurship, agglomeration and technological change. Small Bus Econ 24(3):323-334

Ajzen I (1991) The theory of planned behavior. Organ Behav Hum Decis Process 50:179-211

Alam MS, Biswas K, Sulphey MM (2021) A case study on the entrepreneurial process of push and pull women entrepreneurs. South Asian J Bus Manag Cases 10(2):207-217

Anggadwita G, Ramadani V, Permatasari A, Alamanda DT (2021) Key determinants of women's entrepreneurial intentions in encouraging social empowerment. Serv Bus 15(2):309-334

Aparicio S, Urbano D, Audretsch D (2016) Institutional factors, opportunity entrepreneurship and economic growth: panel data evidence. Technol Forecast Soc Change 102:45-61

Ardagna S, Lusardi A (2010) 1. Explaining international differences in entrepreneurship. University of Chicago Press, pp 17-62

Arenius P, Minniti M (2005) Perceptual variables and nascent entrepreneurship. Small Bus Econ 24(3):233-247

Audretsch DB (2014) From the entrepreneurial university to the university for the entrepreneurial society. J Technol Transf 39(3):313-321

Audretsch DB, Keilbach M (2008) Resolving the knowledge paradox: knowledge-spillover entrepreneurship and economic growth. Res Policy 37(10):1697-1705

Audretsch DB, Keilbach MC, Lehmann EE (2006) Entrepreneurship and economic growth. Oxford University Press, Oxford

Audretsch DB (2012) Determinants of high-growth entrepreneurship. In: Report prepared for the OECD/ DBA International Workshop on High-Growth Firms: local policies and local determinants

Badal S (2010) Entrepreneurship and job creation. Gallup Inc, New Jersey

Bandura A (1992) Exercise of personal agency through the self-efficacy mechanism. In: Schwartzer R (ed) Self-efficacy: thought control of action. Hemisphere, Washingto, pp 3-38

Bandura A (2010) Self-efficacy. The Corsini encyclopedia of psychology. Wiley, New Jersy, pp 1-3

Baumol WJ (2005) Education for innovation: entrepreneurial breakthroughs versus corporate incremental improvements. Innov Policy Econ 5:33-56

Becker GS (1994) Human capital revisited. Human capital: a theoretical and empirical analysis with special reference to education, 3rd edn. The University of Chicago Press, Chicago, pp 15-28

Becker GS (1964) Human capital: a theoretical and empirical analysis, with special reference to education. University of Illinois at Urbana-Champaign's Academy for Entrepreneurial Leadership Historical Research Reference in Entrepreneurship. https://ssrn.com/abstract=1496221. Accessed 3 Nov 2020

Bergmann H, Sternberg R (2007) The changing face of entrepreneurship in Germany. Small Bus Econ 28:205-221

Bird B (1988) Implementing entrepreneurial ideas: the case for intention. Acad Manag Rev 13(3):442-453

Block JH, Wagner M (2010) Necessity and opportunity entrepreneurs in Germany: characteristics and earning s differentials. Schmalenbach Bus Rev 62(2):154-174

Block JH, Kohn K, Miller D, Ullrich K (2015) Necessity entrepreneurship and competitive strategy. Small Bus Econ 44(1):37-54

Bosma NS, van Praag CM, Thurik AR, de Wit G (2004) The value of human and social capital investments for the business performance of startups. Small Bus Econ 23(3):227-236

Bosma N, Hessels J, Schutjens V, Van Praag M, Verheul I (2012) Entrepreneurship and role models. J Econ Psychol 33(2):410-424

Boyd NG, Vozikis GS (1994) The influence of self-efficacy on the development of entrepreneurial intentions and actions. Entrep Theory Pract 18:64-77

Brünjes J, Diez JR (2013) 'Recession push' and 'prosperity pull' entrepreneurship in a rural developing context. Entrep Reg Dev 25(3-4):251-271

Brush CG, Greene PG (2021) Do women engage differently in entrepreneurship? The Palgrave handbook of minority entrepreneurship. Palgrave Macmillan, Cham, pp 139-158

Burt G (1992) Structural holes. Harvard University Press, Cambridge, p 9

Byrne D, Gouaux C, Griffitt W, Lamberth J, Murakawa NBPM, Prasad M, Ramirez M III (1971) The ubiquitous relationship: attitude similarity and attraction: a cross-cultural study. Human Relat 24(3):201-207 
Cacciotti G, Hayton JC (2014) Fear of failure and entrepreneurship: a review and direction for future research. Enterp Res Centre 24(1):1-62

Cacciotti G, Hayton JC, Mitchell JR, Giazitzoglu A (2016) A reconceptualization of fear of failure in entrepreneurship. J Bus Ventur 31(3):302-325

Caliendo M, Kritikos AS (2019) "I want to, but I also need to": start-ups resulting from opportunity and necessity. In: Lehmann EE, Keilbach M (eds) From industrial organization to entrepreneurship. Springer, Cham

Cardella GM, Hernández-Sánchez BR, Sánchez-García JC (2020) Women entrepreneurship: a systematic review to outline the boundaries of scientific literature. Front Psychol. https://doi.org/10.3389/ fpsyg.2020.01557

Chaves R, Monzón JL (2012) Beyond the crisis: the social economy, prop of a new model of sustainable economic development. Serv Bus 6(1):5-26

Chen CC, Greene PG, Crick A (1998) Does entrepreneurial self-efficacy distinguish entrepreneurs from managers? J Bus Ventur 13(4):295-316

Cruz-Ros S, Garzon D, Mas-Tur A (2017) Entrepreneurial competencies and motivations to enhance marketing innovation in Europe. Psychol Mark 34(11):1031-1038

Darnihamedani P, Terjesen S (2020) Male and women entrepreneurs' employment growth ambitions: the contingent role of regulatory efficiency. Small Bus Econ 3:1-20

Dencker JC, Gruber M, Shah SK (2009) Individual and opportunity factors influencing job creation in new firms. Acad Manag J 52(6):1125-1147

Do Paço A, Ferreira JM, Raposo M, Rodrigues RG, Dinis A (2015) Entrepreneurial intentions: is education enough? Int Entrep Manag J 11(1):57-75

Doepke M, Tertilt M (2019) Does female empowerment promote economic development? J Econ Growth 24(4):309-343

Dos Reis CRDA, Castillo MAS, Dobón SR (2007) Diversity and business performance: 50 years of research. Serv Bus 1(4):257-274

Duflo E (2012) Women empowerment and economic development. J Econ Lit 50(4):1051-1079

Eccles JS (1994) Understanding women's educational and occupational choices: applying the Eccles et al. model of achievement-related choices. Psychol Women Q 18(4):585-609

Eckel CC, Grossman PJ (2003) Forecasting risk attitudes: an experimental study of actual and forecast risk attitudes of women and men. Virginia Tech Department of Economics Working Paper

Fairlie RW, Fossen FM (2018) Opportunity versus necessity entrepreneurship: Two components of business creation, SOEP papers on multidisciplinary panel data research, No. 959, Deutsches Institut für Wirtschaftsforschung (DIW), Berlin

Florea AM, Bercu F, Radu RI, Stanciu S (2019) A fuzzy set qualitative comparative analysis (fsQCA) of the agricultural cooperatives from south east region of Romania. Sustainability 11(21):5927

Forrester JW (1971) World dynamics. Wright-Allen Press, Cambridge

Forret ML (2006) The impact of social networks on the advancement of women and racial/ethnic minority groups. Gend, Ethn, Race Workplace 3:149-166

Fritsch M, Mueller P (2004) Effects of new business formation on regional development over time. Reg Stud 38(8):961-975

Gawel A (2021) The gender-based attainment of education and female entrepreneurship: the European perspective. Entrep Sustain Issues 8(4):403

Georgeta I (2012) Women entrepreneurship in the current international business environment. CogitoMultidiscip Res J 1:122-131

Giacomin O, Janssen F, Guyot JL, Lohest O (2011) Opportunity and/or necessity entrepreneurship? The impact of the socio-economic characteristics of entrepreneurs. MPRA Paper. https://mpra. ub.uni-muenchen.de/id/eprint/29506. Accessed 3 Nov 2020

Gibson DE (2004) Role models in career development: new directions for theory and research. J Vocat Behav 65(1):134-156

Grant R (1996) Toward a knowledge-based theory of the firm. Strateg Manag J 17:109-122

Haus I, Steinmetz H, Isidor R, Kabst R (2013) Gender effects on entrepreneurial intention: a metaanalytical structural equation model. Int J Gend Entrep 5(2):130-156

Hisrich RD, Brush CG (1985) Women and minority entrepreneurs: a comparative analysis. Frontiers of entrepreneurship research. Boston Center for Entrepreneurial Studies, Wellesley, p 566

Ibarra H (1992) Homophily and differential returns: sex differences in network structure and access in an advertising firm. Adm Sci Q 37:422-447 
Johnson JEV, Powell PB (1994) Decision making, risk and gender: are managers different? Br J Manag 5(2):123-138

Kelley DJ, Brush CG, Greene PG, Litovsky Y (2010) Global entrepreneurship monitor 2010 women's report. Babson College, Babson Park

Klyver K, Grant S (2010) Gender differences in entrepreneurial networking and participation. Int J Gend Entrep 2(3):213-227

Koellinger P, Minniti M, Schade C (2013) Gender differences in entrepreneurial propensity. Oxford Bull Econ Stat 75(2):213-234

Kolstad I, Wiig A (2015) Education and entrepreneurial success. Small Bus Econ 44(4):783-796

Krueger NF Jr, Brazeal DV (1994) Entrepreneurial potential and potential entrepreneurs. Entrep Theory Pract 18(3):91-104

Krueger NF, Carsrud AL (1993) Entrepreneurial intentions: applying the theory of planned behavior. Entrep Reg Dev 5:315-330

Lazear EP (2004) Balanced skills and entrepreneurship. Am Econ Rev 94(2):208-211

Le A (1999) Empirical studies of self-employment. J Econ Surv 13(4):381-416

Lucas WA, Cooper SY (2012) Theories of entrepreneurial intention and the role of necessity. In: Proceedings of the 35th Institute of Small Business and Entrepreneurship Conference 2012, pp 7-8

Manolova TS, Brush CG, Edelman LF (2008) What do women entrepreneurs want? Strateg Change 17(3-4):69-82

Markussen S, Røed K (2017) The gender gap in entrepreneurship-the role of peer effects. J Econ Behav Organ 134:356-373

Martínez-Rodríguez I, Quintana-Rojo C, Gento P, Callejas-Albiñana FE (2021) Public policy recommendations for promoting female entrepreneurship in Europe. Int Entrep Manag J. https://doi. org/10.1007/s11365-021-00751-9

Morales-Gualdrón ST, Roig S (2005) The new venture decision: an analysis based on the GEM project database. Int Entrep Manag J 1(4):479-499

Nair SR (2020) The link between women entrepreneurship, innovation and stakeholder engagement: a review. J Bus Res 119:283-290

$\mathrm{Ng}$ L, Jenkins AS (2018) Motivated but not starting: how fear of failure impacts entrepreneurial intentions. Small Enterp Res 25(2):152-167

Orhan M, Scott D (2001) Why women enter into entrepreneurship: an explanatory model. Women Manag Rev 6(5):232-247

Poschke M (2013) 'Entrepreneurs out of necessity': a snapshot. Appl Econ Lett 20(7):658-663

Ragin CC (1987) The comparative method. Moving beyond qualitative and quantitative strategies. University of California Press, Berkeley

Ray DM (1994) The role of risk-taking in Singapore. J Bus Ventur 9(2):157-177

Reynolds PD (2015) Business creation stability: why is it so hard to increase entrepreneurship? Foundations and Trends® Entrep 10(5-6):321-475

Reynolds P, Bosma N, Autio E, Hunt S, De Bono N, Servais I, Chin N (2005) Global entrepreneurship monitor: data collection design and implementation 1998-2003. Small Bus Econ 24(3):205-231

Rocha V, Van Praag M (2020) Mind the gap: the role of gender in entrepreneurial career choice and social influence by founders. Strateg Manag J 41(5):841-866

Rothblum ED (1990) Fear of failure. In: Leitenberg H (ed) Handbook of social and evaluation anxiety. Springer, Boston

Runde J (1998) Clarifying Frank Knight's discussion of the meaning of risk and uncertainty. Camb J Econ 22(5):539-546

Sarfaraz L, Faghih N, Majd AA (2014) The relationship between women entrepreneurship and gender equality. J Glob Entrep Res 4(1):1-11

Sexton D, Vesper V (1982) Encyclopedia of entrepreneurship. Prentice Hall, New Jersey

Shane S (2000) Prior knowledge and the discovery of entrepreneurial opportunities. Organ Sci 11(4):448-469

Shapero A, Sokol L (1982) The social dimensions of entrepreneurship. In: Kent CA, Sexton DL, Vesper KH (eds) Encyclopedia of entrepreneurship. Prentice Hall, NJ, pp 72-88

Sibanda K (2020) An empirical study of Women Entrepreneurship motivational factors in Botswana. Int J Bus, Manag Econ 1(2):1-14

Strobl A, Kronenberg C, Peters M (2012) Entrepreneurial attitudes and intentions: assessing gender specific differences. Int J Entrep Small Bus 15(4):452-468 
Stuetzer M, Obschonka M, Davidsson P, Schmitt-Rodermund E (2013) Where do entrepreneurial skills come from? Appl Econ Lett 20(12):1183-1186

Ucbasaran D, Westhead P, Wright M (2008) Opportunity identification and pursuit: does an entrepreneur's human capital matter? Small Bus Econ 30(2):153-173

Udimal TB, Luo M, Liu E, Mensah NO (2020) How has formal institutions influenced opportunity and necessity entrepreneurship? The case of brics economies. Heliyon 6(9):31

Van der Sluis J, Van Praag M, Vijverberg W (2008) Education and entrepreneurship selection and performance: a review of the empirical literature. J Econ Surv 22(5):795-841

Van Stel A, Kaciak E, Cieślik J (2020) Hiring plans by solo entrepreneurs at the time of start-up: the role of education and the desire for self-expression. J Bus Res 119:58-66

Velásquez JCC, Duarte MN, Rojas AKS, Carvajal MFA, Arias NCA, Martínez C, Arias RM (2008) Resiliencia en mujeres emprendedoras de la base de la pirámide (BoP): una aproximación desde la literatura. La base de la pirámide y la innovación frugal en América Latina, 225

Wagner J (2003) Testing Lazear's jack-of-all-trades view of entrepreneurship with German micro data. Appl Econ Lett 10(11):687-689

Wagner J (2007) What a difference a Y makes-women and male nascent entrepreneurs in Germany. Small Bus Econ 28(1):1-21

Wagner J (2005) Nascent necessity and opportunity entrepreneurs in Germany: evidence from the regional entrepreneurship monitor (REM) (Discussion paper No. 1608)

Warnecke T (2013) Entrepreneurship and gender: an institutional perspective. J Econ Issues 47(2):455-464

Wennekers S, Van Wennekers A, Thurik R, Reynolds P (2005) Nascent entrepreneurship and the level of economic development. Small Bus Econ 24(3):293-309

Wilson F, Kickul J, Marlino D (2007) Gender, entrepreneurial self-efficacy, and entrepreneurial career intentions: Implications for entrepreneurship education. Entrep Theory Pract 31(3):387-406

Wyrwich M, Stuetzer M, Sternberg R (2016) Entrepreneurial role models, fear of failure, and institutional approval of entrepreneurship: a tale of two regions. Small Bus Econ 46(3):467-492

Xie Z, Wang X, Xie L, Dun S, Li J (2021) Institutional context and female entrepreneurship: a countrybased comparison using fsQCA. J Bus Res 132:470-480

Publisher's Note Springer Nature remains neutral with regard to jurisdictional claims in published maps and institutional affiliations. 